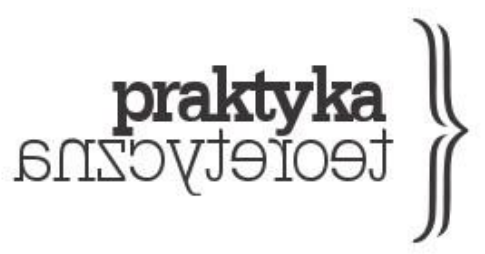

ISSN 2081-8130

DOI: $10.14746 /$ prt.2016.3.5 www.praktykateoretyczna.pl

\title{
POCHWAKA DONKISZOTERII, CZYLI O TYM, CO STRUKTURALIZM WNIÓSŁ I WCIĄŻ MOŻE WNIEŚĆ DO HISTORII
}

\author{
TOMASZ FALKOWSKI
}

\begin{abstract}
Abstrakt: Artykuł powraca do związków między strukturalizmem a historią i stawia problem aktualnych możliwości zastosowania inspiracji strukturalistycznych w badaniach historycznych. Jednym z pól takiego płodnego mariażu może być kwestia rozważań genetycznych. Jako przykład potwierdzający znaczenie myślenia strukturalistycznego w kontekście pytania o genezę danego zjawiska historycznego została wykorzystana analiza Michela Serres’a odnosząca się do problemu pochodzenia geometrii.
\end{abstract}

Słowa kluczowe: strukturalizm a historia, problem genezy, pochodzenie geometrii, Michel Serres 
Postawić dzisiaj raz jeszcze pytanie o relacje między strukturalizmem (i jego dziedzictwem) a historią to nieuchronnie umieścić się w sytuacji jako żywo przypominającej tę, w której swego czasu znalazł się Don Kichot. Zaczytani w opowieściach o indoeuropejskich bogach, formach walki greckich wojowników, wysiłkach siedemnastowiecznych gramatyków i naturalistów, pochłonięci przez intelektualne przygody, spory, potyczki i nadzieje iście błędnych rycerzy myśli ubiegłego stulecia, sami chcielibyśmy - niczym biedny hidalgo ruszyć z miejsca i wciąż powalczyć przynajmniej o część stawek, rozstrzygnięć i kruchych zdobyczy, które zawdzięczamy Dumézilowi, Vernantowi, Lévi-Straussowi, Foucaultowi i kilku innym. Ale podobnie jak szesnastowieczna Hiszpania nie była już miejscem dla następców Cyda, tak współczesna przestrzeń wiedzy stała się środowiskiem obcym dla strukturalistycznego, a nawet poststrukturalistycznego bohatera. Bez wątpienia: nie jesteśmy już w 1967 roku. Strukturalizm uznano za zamknięty i summa summarum zakończony niepowodzeniem rozdział w dziejach europejskiej myśli. Ci, którzy ze strukturalizmu wyrastali (ostatni z nich jeszcze żyją, na przykład Michel Serres), coraz częściej padają ofiara prostych kategoryzacji (French Theory), zarzutów o obskurantyzm, oskarżeń o intelektualny terroryzm. Są to oczywiście jedynie najprostsze przejawy dużo głębszych procesów zachodzących aktualnie w polu epistemologicznym naszej wiedzy. Jedna z ostatnio wysuniętych hipotez: oto w miejscu eksplorowanym niegdyś przez nauki humanistyczne, a zwłaszcza przez te dyscypliny, które stanowiły ich radykalną formę, wyznaczały ich granice, kontestowały niejako od wewnątrz - etnologię, psychoanalizę, lingwistykę - wyłonił się wszechobejmujący, dwuwymiarowy i nieskończenie podzielny obszar kultury, gdzie w wymiarze poznawczym „obowiązuje zasada mikrologicznej skromności, ograniczenia i natychmiastowej ekstrapolacji” (Florczyk 2015, 320). Zrozumiałe, że nie jest to miejsce dla ryzykownych, wyczerpujących, czasem też zuchwałych i prowadzących w nieznane badań, tak charakterystycznych dla „heroicznej” epoki sprzed półwiecza. Świat niebezpiecznych wypraw i trudno dostępnych twierdz (nieświadomości, języka itd.) przeobraził się w równinną krainę złożoną z wielu podobnych do siebie prowincji, gdzie w przydrożnych karczmach (nad którymi, również tutaj, coraz częściej góruje zółte M) bez większego trudu snuje się lokalne mikroopowieści. Świadomość ta oczywiście sprawia, że powracając do kwestii związków na linii historia - (post-)strukturalizm, ostatecznie lokujemy się w pozycji nie tyle Don Kichota, co jego wiernego sługi Sancho Pansy. Pragnęlibyśmy podążyć śladami niegdysiejszych śmiałków, lecz nie jesteśmy w stanie uciec przed widokiem analitycznych młynów tworzących 
nasz swojski, jednostajny krajobraz. Czy ktoś kiedyś widział, by można było walczyć, wygrać z wiatrakami? Czy jednak również i Sancho Pansa nie uległ płonnym marzeniom, wierząc, że u boku Don Kichota zdoła objąć władzę nad obiecaną mu wyspą? Zreszta, jak świetnie wiemy, szturm na wiatraki nie może nikomu wyrządzić szkody - z wyjątkiem rzecz jasna tego, kto decyduje się na tak mało dorzeczny czyn.

Jak zatem moglibyśmy dziś spojrzeć na związki między strukturalizmem i wyrastającymi z niego tendencjami a badaniami historycznymi? I co, przede wszystkim, warte byłoby tu zachowania, wzmocnienia, afirmatywnego gestu wsparcia? Jak wiadomo, w podręcznikowych i przez to najbardziej rozpowszechnionych ujęciach istotą strukturalizmu jest wyniesienie poziomu synchronii nad poziom diachronii, przez co w analizie nie uwzględnia się wymiaru czasu, bez którego historia nie może się obyć. Stąd badania prowadzone w takim duchu - omijające problem przypadkowych zmian, poszukujące trwałych systemowych relacji w takiej czy innej domenie - byłyby z gruntu ahistoryczne czy wręcz antyhistoryczne. Nie ulega wątpliwości, że takie ujęcie nie było i nie jest bezpodstawne. Wystarczy przypomnieć polemikę Lévi-Straussa z Sartrem, w której historia zostaje określona przez tego pierwszego jako jedynie punkt wyjścia dla poszukiwania wszelkiej postaci zrozumiałości (Lévi-Strauss 2001, 348). Można również, niejako symetrycznie, przywołać obawy Fernanda Braudela, który w swym programowym tekście o długim trwaniu przeciwstawia tytułowe pojęcie uniwersalizującym zapędom antropologii strukturalnej (Braudel 1999, 75 i nn.). Przykładów z obu stron nie brakuje. Z tym że właśnie uwypuklanie tej empirycznej podbudowy wzmacniającej tezę o istotowym charakterze opozycji między historia a strukturalizmem jest o tyle zwodnicze i szkodliwe, o ile przysłania potencjalnie dużo ciekawsze i bardziej wartościowe relacje łączące obie te perspektywy. Prowadzi to bowiem często do następującego rozumowania: jak można na poważnie traktować aktywność poznawcza, która nie bierze pod uwage zmienności, czasu, pojawiania się nowych zjawisk, a więc samej treści naszej rzeczywistości, która potwierdza na każdym kroku i nasze doświadczenie wewnętrzne, i właściwie każda forma obserwacji? Czy w konsekwencji strukturalizm, usiłujący odnaleźć poza historycznością transkulturowe niezmienniki, już w punkcie wyjścia nie był skazany na porażkę, albowiem tak naprawdę „nie da się uciec od historii"? Stąd tylko krok od zamknięcia strukturalistycznej przygody na cztery spusty i uczynienia z niej przedmiotu badań dla tradycyjnego historyka idei.

Tymczasem dość wcześnie zauważono, że analiza strukturalna wcale nie musi być wroga podejściu historycznemu, co więcej, może dostarczać mu pewnych narzędzi pozwalających w ściślejszy, a zarazem bardziej kompleksowy sposób zmierzyć się z problemem zmienności. Jednym z bardziej znanych przykładów takiej diagnozy jest pochodzący z 1972 roku tekst Foucaulta zatytułowany Powrót do historii (Foucault 2000). 
Foucault stawia w nim następująca tezę: pierwsze próby zastosowania metody strukturalistycznej w etnologii, językoznawstwie, religioznawstwie czy krytyce literackiej bynajmniej nie odwracały się od historii, lecz w badanych przez siebie obszarach usiłowały wyznaczyć taki poziom, takie dziedziny przedmiotowe, których historyczność wymyka się ogólnemu modelowi ewolucyjnemu, dając się przez to analizować w złożonej grze różnic, trwań, nieciagłości i przekształceń. Strukturalizm zatem, przynajmniej na początku, wcale nie zamierzał zubo:̇yó naszej wizji rzeczywistości o wymiar historyczny, lecz - przeciwnie - staral się wąbogacić go o nowe parametry.

Pochylając się bliżej nad przykładem zaczerpniętym z mitologii porównawczej Dumézila, Foucault wskazuje w swoim tekście na jedną z możliwych form takiego wzbogacenia. Otóż dzięki uwidocznieniu wieloaspektowej przemiany jednego wariantu opowieści indoeuropejskiej w drugi (irlandzkiego podania o Cûchulainnie w rzymską legendę o Horacjuszach) i powiązaniu tego procesu z odmiennością dwóch starożytnych organizacji społecznych Dumézil miał odsłonić zbiór zewnętrznych, historycznych warunków, w jakich dany „system zdolny do przekształceń” ulega właśnie takim a nie innym transformacjom. Analiza strukturalna pozwalałaby więc na bazie układu różnic stwierdzonych w obrębie jednego porządku (np. społecznego) uchwycić kierunek i charakter zmian zaszłych w porządku drugim (np. mitycznym).

Wydaje się, że można rozszerzyć refleksję Foucaulta, pokazując na innych przykładach, w jaki sposób strukturalizm i płynące z niego inspiracje sproblematyzowały na nowo kwestię genesyy zjawisk - a zatem jeden z podstawowych komponentów historycznego myślenia. Zagadnienie to jest oczywiście pokrewne przedsięwzięciu Dumézila, ale o ile jego pytanie brzmiało: „w jakich egzogenicznych warunkach możliwe było przekształcenie jednego układu w drugi?”, o tyle pewni myśliciele o strukturalistycznej proweniencji wprost atakowali problem pochodzenia, problem źródeł określonych fenomenów historycznych. Niechaj w wędrówce po tej sferze łączącej strukturalizm i historię za nić przewodnią posłużą nam dociekania Michela Serres'a nad początkami geometrii.

Wybór to nieprzypadkowy w tej mierze, w jakiej kwestia pojawienia się w starożytności wiedzy geometrycznej nurtowała od dawna i historyków, i filozofów wywodzących się z odmiennych tradycji myślowych, co powoduje, że mamy do dyspozycji szerokie i różnorodne tło porównawcze, na którym można wyraźniej dostrzec specyfikę podejścia strukturalistycznego (czy też wyrastającego $z$ takowego). Nie pretendując do przedstawienia panoramy wszystkich stanowisk, jakie zaistniały dotychczas w odniesieniu 
do tej problematyki, wymieńmy jedynie kilka z nich - tych najbardziej obiegowych, najbardziej znanych, najczęściej przywoływanych.

Pierwsze stanowisko, przynajmniej w swej wyjściowej postaci, jest swoistym ominięciem problemu jako takiego: narodziny matematyki w starożytnej Grecji miały być prawdziwym cudem, zupełnie nieoczekiwanym zdarzeniem, co więcej, nauka ta powstała nagle, nieomal w jednej chwili, na dodatek w integralnej formie. Przekonanie to ma długa tradycję, w XIX wieku wyrażali je między innymi Ernest Renan i Paul Tannery, ale przewija się ono również we współczesnych pracach z historii i filozofii nauki (por. np. Prigogine, Stengers 1990, 12). Nie zawsze, rzecz jasna, zwolennicy takiego twierdzenia poprzestaja wyłącznie na nim: można mówić o zaskakującym i gwałtownym charakterze powstania geometrii, a jednocześnie dociekać jej historycznej genezy. Ta zaś - już niezależnie od akceptacji bądź odrzucenia owego przeświadczenia - rekonstruowana jest zgodnie z następującymi przesłankami.

Po pierwsze, regularnie jako rozwiązanie problemu przytacza się po prostu to, co na temat źródeł geometrii podają sami Grecy. Najczęściej w tym kontekście wykorzystywany jest fragment z Księgi Drugiej Dziejów Herodota, w której grecki historyk wywodzi geometrię ze społeczno-politycznych realiów państwa egipskiego za panowania króla Sezostrysa. Po podziale ziemi na równe czworokątne grunty w celach fiskalnych wylewy Nilu zmusily władcę i jego urzędników do cyklicznego odmierzania, jak dużą powierzchnię działki zabrała woda i w konsekwencji o ile mniejszy podatek winien w przyszłości zapłacić jej właściciel (Herodot, 98). Krótko mówiąc, geometria wyłoniła się z problemów natury praktycznej i tezę tę można spotkać w wielu opracowaniach i podręcznikach (por. np. Nagel 1970, 12). W tym samym trybie, choć rzadziej, przywołuje się również uwagi Arystotelesa o mającej sporo wolnego czasu (otium litteratum) egipskiej warstwie kapłańskiej jako środowisku-kolebce nauk matematycznych (Arystoteles 1996, 9).

Drugi zbiór odpowiedzi na pytanie o genezę geometrii - udzielanych zwłaszcza przez matematyków piszących historię matematyki - opiera się na wyliczeniu kolejnych chronologicznie twierdzeń, dowodów i formuł, jakie da się zidentyfikować od na poły legendarnych dokonań Talesa w VI wieku p.n.e. aż po pierwsze znane nam systematyczne ujęcie geometrycznych aksjomatów w dziele Euklidesa. Przyjmuje to zazwyczaj formę swoistego połączenia kroniki wydarzeń (matematycznych) z pedagogicznym wykładem 
na temat doniosłości każdego z nich; ponadto wszystkie „odkrycia”, o ile jest to możliwe, noszą obowiązkowo znamię swego autora-odkrywcy ${ }^{1}$.

Osobne miejsce wśród tych genetycznych rozważań należałoby przyznać fenomenologii Edmunda Husserla, która znalazła jeden ze swych ostatnich wyrazów w jego słynnym tekście Ursprung der Geometrie. Ktoś mógłby oczywiście zaprotestować, że idzie tu o projekt czysto filozoficzny, a nawet metafizyczny, niezależny zatem od poszukiwań historycznych. Rzecz jest jednak nieco bardziej złożona, Husserl bowiem dość klarownie sytuuje rozwijaną przez siebie myśl zarówno wobec pracy historyka, jak i jego przedmiotu badań. Najpierw więc wyraźnie zaznacza, że postawione przez niego pytanie o pochodzenie geometrii ${ }^{2}$ nie ma charakteru historyczno-filologicznego (rozumianego grosso modo zgodnie z modelem kronikarsko-pedagogicznym, który przypomnieliśmy przed chwila), ponieważ „odsłania głębokie problemy, zupełnie obce zwykłej historii, problemy, które w swoim rodzaju są niewątpliwie także problemami historycznymi” (Husserl 1991, 10), co dość jednoznacznie sugeruje, że tradycyjna historia nie jest zdolna ich podjąć. Sugestia ta uzasadniona zostaje przez stosunek fenomenologii do historii jako tego, czym zajmuje się historyk, gdyż celem Husserla jest właśnie wykroczenie poza dzieje geometrii i odnalezienie pod nimi jej transcendentalnych warunków możliwości. Zarówno więc pod względem metodologicznym, jak i przedmiotowym fenomenologia góruje nad badaniami historycznymi, albowiem tylko ona dzięki ukazaniu struktury a priori otwiera drogę do zasadniczego pytania o źródłowy sens, który nadał całej historii geometrii - tej przeszłej i tej przyszłej - jej sens prawdziwościowy. Analiza fenomenologiczna chciałaby otoczyć historyczną zmienność ze wszystkich stron.

Jak na tym tle - bardziej w tym miejscu zasygnalizowanym aniżeli zrekonstruowanym choćby w drobnej mierze - przedstawia się propozycja Serres’a, jednego z niewielu, jak chca niektórzy, myślicieli francuskich w XX wieku faktycznie wykorzystujących metodę strukturalną do analizy zjawisk kultury (Descombes 1997, 102)? W swych ponad dwudziestoletnich rozważaniach nad pochodzeniem geometrii, znaczonych kolejnymi tekstami na ten temat (od krótkich szkiców zawartych w tomach z „Hermesowego” cyklu aż po osobna książkę z 1993 roku), Serres właściwie nie wchodził w otwartą polemikę z tradycyjnymi, wcześniejszymi ujęciami owego zagadnienia. Można jednak odczytywać jego podejście jako próbę uniknięcia ich podstawowych słabości. Czy powtórzenie za Herodotem prostego zestawienia dwóch faktów - egipskiej praktyki mierzenia gruntów i wyłonienia się w starożytnej Grecji zbioru twierdzeń o figurach idealnych - cokolwiek rzeczywiście wyjaśnia? W jaki sposób przechodzi się od problemów natury społecznej czy politycznej

\footnotetext{
1 Por. np. hasło Géométries i podrozdział La géométrie grecque we francuskim słowniku historii i filozofii nauk (Patras 2014, 539).

${ }^{2}$ Geometrii przyjmującej u Husserla, rzecz jasna, sens metonimiczny.
} 
do porządku czysto teoretycznego? Jak rozumieć to przejście 3 ? Ponadto czy od czasów historyków greckich nie posunęliśmy się ani o krok w budowaniu modeli i schematów wyjaśniających? Czy i w tym przypadku nie należy odejść od „optyki źródeł”? Dalej: czy historia geometrii pisana przez matematyków zgodnie z następstwem kolejnych autorskich odkryć milcząco nie odsyła w ostatniej instancji do czynnika indywidualnego geniuszu, który - raz jeszcze - niczego tak naprawdę nie tłumaczy? Skądinąd również Husserl zdaje się kłaść silny nacisk na ten czynnik, mówiąc o „pierwotnym wewnątrzosobowym źródle”, subiektywnej świadomości pierwszego odkrywcy, z której dopiero później może wyłonić się obiektywny wytwór geometryczny w swej idealności.

Tymczasem Serres wychodzi od następującego założenia: nie ma jednego źródła geometrii, jej powstanie jest efektem czy też konfluencją wielu dopływów, stąd w sensie analitycznym niezbędna staje się „proliferacja genez”, poszukiwanie genezy praktycznej, zmysłowej, epistemologicznej, konceptualnej, estetycznej, rytualnej i tak dalej (Serres 1982, 87). Towarzyszy temu drugi wymóg, a mianowicie konieczność uchwycenia, do czego tak właściwie doszło wraz z narodzinami geometrii, jaki zbiór nowych elementów, form czy relacji się wówczas pojawił? Wreszcie trzecia wstępna myśl: nie należy dzielić starożytnych przekazów na te bardziej wiarygodne i te bardziej legendarne, ponieważ mit może zawierać w sobie równie wiele racjonalnych informacji, co wypowiedź racjonalna treści mitycznych (Serres 1982, XIX). Wyodrębniwszy w punkcie wyjścia najogólniejsze przesłanki rozumowania Serres'a, spróbujmy je teraz pokrótce przybliżyć.

Geneza geometrycznego zapisu. Geometria to połączenie dwóch języków, podwójny system notacji: z jednej strony figury, schematy, diagramy, z drugiej strony litery, słowa, wzory, zdania-twierdzenia. Z pewnego punktu widzenia istota geometrii polega na tym, że jeden język jest w stanie wyrażać drugi, że relacje przestrzenne pozwalają się ująć w symbolicznych równaniach oraz konstrukcjach słownych i odwrotnie. Ta relacja jezzykowej przekładalności istniejąca w samym wnętrzu omawianej dziedziny stanowi zarazem jeden z podstawowych i niezbywalnych motorów jej historii, gdyż to, co potencjalnie tkwi w jednym podsystemie, pozwala na rozwój podsystemu drugiego. Zdarza się na przykład, że

\footnotetext{
dany schemat zawiera więcej informacji niż całe linijki pisanego tekstu, że linijki te bez końca wykładają to, co wykreślamy ze schematu, czerpiąc z niego jak ze studni lub rogu obfitości. Starożytna algebra zapisuje, wydobywa na jaw - linijka po linijce - to, co dyktują jej figury starożytnej geometrii, co zawieraja w sobie tu i teraz (Serres 1982, 127).
}

\footnotetext{
${ }^{3}$ Nie oznacza to oczywiście, że Serres nie wykorzystuje opowieści Herodota w celu rekonstrukcji jednej z linii genetycznych geometrii (por. Serres 1993, 313 -337).
} 
Jak wiadomo, wiele antycznych przekazów wskazuje pośrednio na rolę kontaktów greckoegipskich w narodzinach geometrii (Tukidydes, Diogenes Laertios, Demokryt, Platon). W dotychczasowych dyskusjach na temat ich znaczenia pomija się jednak, zdaniem Serres'a, rzecz najistotniejszą, to znaczy fakt, że Egipcjanie używali do zapisu hieroglifów, ideogramów, a Grecy alfabetu. A czym są okręgi, trójkąty, kwadraty i inne figury, jeśli nie znakami ideograficznymi, uproszczonymi obrazami form obecnych $\mathrm{w}$ świecie? W konsekwencji nie ma sensu spierać się o to, czy palmę pierwszeństwa w wymyśleniu geometrii należy przyznać Egipcjanom czy Grekom; trzeba raczej przyjąć, że mogło do tego dojść w wyniku prawdziwego skomunikowania się obu kultur, prawdziwego porozumienia sie między nimi przy użyciu właściwych im systemów piśmiennych.

\begin{abstract}
Historyczna więź Grecji z Egiptem daje się pomyśleć jako związek alfabetu ze zbiorem ideogramów, a ponieważ geometria nie może istnieć bez zapisu (matematyka funkcjonuje raczej w piśmie niż w mowie) więź ta ustanowiona zostaje w geometrii jako działanie wykorzystujące podwójny system zapisu. [...] Rozwiązuje to również inny historyczny problem: brutalny kres geometrii w Egipcie, jej stężenie, krystalizacja w nieruchomych ideogramach, a zarazem niepowstrzymany rozwój, w Grecji i naszej kulturze, nowego języka, niewyczerpanego dyskursu matematyki i porządku, który jest samą historią tej kultury. Inicjalna więź geometrycznego ideogramu z alfabetem, słowami i konstrukcjami zdaniowymi otworzyła przed nami niekończącą się droge (Serres 1982, 128).
\end{abstract}

Geneza geometrii w swietle teorii komunikacji. Geometria to ucieleśnienie w pełni udanej sytuacji komunikacyjnej, w której całkowicie zostaje wyeliminowany szum, a w jego miejsce pojawia się jednoznaczny kod. Jak należy to rozumieć? Pomyślmy najpierw o najbardziej elementarnym układzie, z jakim mamy do czynienia w przypadku każdej rozmowy, każdego dialogu. Otóż, po pierwsze, mamy dwóch rozmówców, których łączy tzw. kanał komunikacyjny (jest to warunek niezbędny do tego, aby mogło w ogóle dojść do czegoś takiego jak dialog). Po drugie jednak, każdej rozmowie od samego początku towarzyszy w tle możliwość informacyjnego szumu (spowodowanego kakofonią, wieloznacznością słów naturalnego języka itd.), który grozi blokadą kanału komunikacyjnego i przerwaniem przepływu informacji na linii łączącej rozmówców. Odwrotnie, pełne porozumienie zakłada zastosowanie w rozmowie takiego kodu, którego elementy będą dla interlokutorów oznaczać dokładnie to samo. Stąd, jak mówi Serres, wbrew tradycyjnej koncepcji „dialektycznej gry” uczestnicy dialogu nie są oponentami, nie walczą ze sobą, lecz sprzymierzają się przeciw temu trzeciemu, przeciw szumowi. 
Podtrzymać dialog to założyć obecność trzeciego człowieka i starać się go wykluczyć: udana komunikacja polega na wykluczeniu trzeciego człowieka. Najgłębszy dialektyczny problem to nie problem Innego, który jest jedynie wariantem - czy też wariacją - Tego Samego; chodzi natomiast o problem trzeciego człowieka (Serres 1982, 67).

Na poziomie pisma, a ściślej: form graficznych, wygląda to podobnie. Tutaj komunikacyjny szum wywoływany jest przede wszystkim przez czystą empirię: wiadomo, że $w$ rzeeczywistości nie sposób wykreślić dwóch identycznych krzywych, wielokątów czy owalów. Omsknięcia ręki, różna grubość zarysu, przypadkowe punkty - wszystko to składa się na coś, co przez analogię do kakofonii zyskało miano kakografii. Geometria, która abstrahuje od tych rzeczywistych odmienności, która wśród de facto różnych obiektów rozpoznaje jedną i tę samą figurę - na przykład trójkąt równoboczny - oznacza dokładnie taką sytuację, gdzie empiryczny szum zostaje zastapiony przez uniwersalny, matematyczny kod. Innymi słowy, uznanie, że z wielorakich konkretnych grafów można otrzymać jedną abstrakcyjną formę, oraz zgoda co do tego rozpoznania sa jednym i tym samym aktem (Serres 1982, 68). Proces idealizacji umożliwiający zaistnienie geometrii wyznacza jednocześnie podstawowy i niezbywalny warunek powstania idealnej wspólnoty komunikacyjnej (matematyków).

Eliminacja „trzeciej osoby” w toku dialogu, wykluczenie empirycznego szumu w matematyce, ruch krańcowej idealizacji i abstrakcji - jest to nie tylko zbieżność logiczna, lecz również ten sam moment historyczny. Jesteśmy w starożytnej Grecji, w czasach Platona. Jaki jest cel sokratejskich dialogów - owej matrycy naukowej i krytycznej dyskusji - jeśli nie osiagnięcie zgody co do wspólnie i dialektycznie zrodzonej prawdy, a więc dojście do komunikacyjnego porozumienia między dwoma rozmówcami? Temu właśnie miała służyć metoda majeutyczna. Z drugiej strony nie sposób nie zauważyć ścisłej korelacji między słynną platońską teoria idei a wyodrębnieniem idealnych form, którymi zajmuje się geometria. Stąd konkluzja Serres'a:

Pierwsze wysiłki dążące do tego, aby komunikacja w dialogu zakończyła się sukcesem, są izomorficzne względem prób uniezależnienia formy od jej empirycznych ucieleśnień. [...] Dialektyczna metoda dialogu wywodzi się z tej samej sfery, co metoda matematyczna, która poza tym również nosi miano dialektycznej (Serres 1982, 69).

Narodziny geometrii należy z tego punktu widzenia rozumieć w dużo szerszym ruchu wykształcania się warunków udanej komunikacji, filozofii dialogu i filozofii poprzez dialog, którą można z kolei wpisać w ogólne przejście od świata „mitu” do świata „nauki”, skoro - 
jak pisał Lévi-Strauss - „w łonie każdego społeczeństwa porządek mitu wyklucza dialog o mitach danej grupy się nie dyskutuje" (Prigogine, Stengers, 337, p. 14).

Geneza epistemologiczna. Jednym ze źródeł geometrii, a więc wyłonienia się abstrakcyjnej przestrzeni, jest prawdopodobnie starożytna astronomia. W jaki sposób w czasach antycznych obserwowano to, co dzieje się na niebie? Oprócz naturalnego, bezpośredniego oglądu rozgwieżdżonego firmamentu ważną rolę odgrywał gnomon. „Od Anaksymandra fizycy greccy potrafili dzięki projekcjom wytwarzanym przez gnomon rozpoznać niektóre zdarzenia zachodzące na niebie" (Serres 1997, 101). Albowiem wbrew potocznej opinii tak zwany zegar słoneczny służył pierwotnie nie tyle do wskazywania godziny, ile do celów poznawczych. Identyfikacja równonocy, przesileń słonecznych, podział nieba na dwanaście sfer (zodionów) - wszystko to odkryto bądź uzyskano za pośrednictwem gnomonu. Zreszta o tej jego podstawowej funkcji zaświadcza również etymologia: gnomon to dosłownie coś, „co poznaje”, „co rozróżnia”. Ów swoisty automat pozwala jednak nie tylko obserwować niebo, lecz również wykreśla ogólny model Ziemi: oś świata, równik, oba zwrotniki, szerokość geograficzną danego miejsca, stopień nachylenia ekliptyki itd. Od VI wieku p.n.e. kolejne pokolenia greckich badaczy „wydzierały” linię po linii tej samoistnie działającej maszynie poznania.

Jak funkcjonuje, jak poznaje gnomon? Otóż nie inaczej jak za pomocą tego, co my określamy mianem form geometrycznych: w prostej technicznie grze światła i cienia wskazówka gnomiczna, zostawiając na prostopadłej względem siebie płaszczyźnie ślady, wykreśla punkty, linie, krzywe, półokręgi, kąty, podstawowe figury. Abstrakcyjna przestrzeń wraz z jej idealnymi elementami rodzi się, paradoksalnie, pośród samych rzeczy, w łonie świata, poza jakakkolwiek postacią idealizmu. Gnomon to materialny, rzeczywisty i niezależny „fałd poznania” (Serres 1997, 109).

O tym, że Grecy wykorzystywali matematyczny potencjał tkwiący w gnomonie, świadczy wiele znaków. Po pierwsze, ponownie słownictwo. W epoce archaicznej zwrot „na modłę gnomonu” odnosił się - wzorem konstrukcji urządzenia - do kąta prostego bądź pionu. Przykładem takiego odniesienia był chociażby ekier czy też węgielnica: z jednej strony przyrząd praktyczny używany przez cieślę do wytyczania kątów prostych, z drugiej coś, co pozwala - poprzez proste dopełnienie - uzyskać dwa komplementarne równoległoboki. Matematyczną definicję tak rozumianego gnomonu odnajdziemy na początku drugiej księgi Elementón Euklidesa4. Drugie przykładowe świadectwo przynosi nam geometryczna arytmetyka Pitagorejczyków, którzy ciag kolejnych liczb naturalnych podniesionych

\footnotetext{
${ }^{4}$ „W równoległoboku, jeżeli poprowadzimy przekątną i przez punkt gdziekolwiek obrany na tej przekątnej, poprowadzimy dwie linie równoległe do boków równoległoboku, równoległobok podzieli się na cztery części; każda z dwóch części, której przekątna jest częścią przekątnej całego równoległoboku, wziętą z dwiema jej przyległymi [częściami] zwać będziemy gnomonem" - tłum. nieznacznie zmienione (Euklides, ks. II, def. 2).
} 
do kwadratu, otrzymywanych przez dodanie kwadratu liczby o jeden niższej do kolejnej liczby nieparzystej, wyrażali nie za pomocą równań o postaci:

$$
\begin{aligned}
& 2^{2}=1^{2}+3 \\
& 3^{2}=2^{2}+5 \\
& 4^{2}=3^{2}+7 \\
& \ldots \\
& (n+1)^{2}=n^{2}+(2 n+1),
\end{aligned}
$$

lecz w formie graficznego sympleksu:

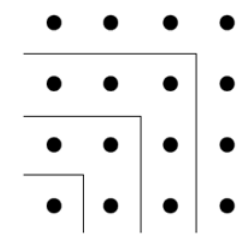

Pitagorejczycy zwali ów geometryczny schemat, jakżeby inaczej, gnomonem, a nieparzyste liczby, dzięki którym otrzymujemy kolejne kwadraty, zyskały miano liczb gnomicznych. Nie chodzi tu jednak wyłącznie o zbieżność terminologiczną. Związek między materialnym gnomonem, węgielnicą a pitagorejską procedurą graficzną jest dużo realniejszy, a zarazem wieloaspektowy. Czy stosunek danego obiektu do rzucanego przezeń cienia - i kolejnych cieni w kolejnych dniach, tygodniach, miesiącach - nie jest izomorficzny względem relacji, jaka istnieje między następującymi po sobie figurami w ramach pitagorejskiego sympleksu? Jakiego aktu dokonuje Tales, kiedy u stóp piramidy próbuje określić jej wysokość za pomocą pomiaru rzucanego przez nią cienia, jeśli nie właśnie gnomicznego przejścia od mniejszego do większego trójkąta? I czy każdorazowe poszerzenie pola tworzące w obrębie sympleksu nowy kwadrat nie jest idealnym modelem wegielnicy?

Z tym że, jak pisze Serres, cała ta geometryczna czy protogeometryczna wiedza gromadzona dzięki gnomonowi bardzo mocno różni się od klasycznie pojmowanej matematyki, która opiera się przede wszystkim na dowodzeniu, na dedukcji. W stosunku do geometrii euklidesowej bazujące na idealnych formach przestrzennych pierwsze odkrycia geograficzne i astronomiczne lub pitagorejska arytmetyka znajdująca swój wyraz w dwuwymiarowej przestrzeni wpisują się „,w inny logos, w odmienną epistemę, słowem, w inną racjonalność, którą z wielką chęcią nazwalibyśmy algorytmiczną" (Serres 1997, 108). Czym byłby ów algorytmiczny rozum? Musimy w tym miejscu jeszcze bardziej cofnać się 
w czasie, by przywołać strukturalne cechy myśli babilońskiej i egipskiej. Jeden z zajmujących się tym zagadnieniem badaczy, James Ritter, zauważył, że w tak, zdawałoby się, heterogenicznych dziedzinach, jak wróżbiarstwo, medycyna, matematyka czy prawo, Babilończycy z II tysiąclecia p.n.e. rozumowali w bardzo podobny sposób, o czym świadczą zachowane z tamtego okresu dokumenty. Otóż w każdej z tych dziedzin istniały dwa rodzaje tekstów lub też - wewnątrz nich - dwie struktury formalne: teksty proceduralne, pokazujące krok po kroku droge prowadzącą do rozwiązania danego problemu, oraz tablice służące jako swoisty indeks elementów bądź działań odnoszących się do zbioru problemów określających wybraną dziedzinę. W medycynie na przykład mamy z jednej strony dążący do kompletności spis poszczególnych części ciała i dotykających je objawów, z drugiej listę procedur leczniczych, jakie należy zastosować w przypadku takich czy innych dolegliwości. I analogicznie wyglądało to w matematyce, w obrębie której odnajdujemy także dwa korpusy tekstów: jeden obejmujący zbiór matematycznych problemów wraz z ich rozwiązaniami (algorytmami), drugi złożony z różnego rodzaju mnemotechnicznych tablic pozwalających na cząstkowe obliczenia (np. tabliczka mnożenia). W konsekwencji „każdy etap danego algorytmu odsyłał milcząco do jakiejś tabeli, gdzie można było odnaleźć liczbowe wartości potrzebne do jego realizacji” (Ritter 1997, 60).

W jakim sensie wiedza otrzymywana dzięki pracy gnomona należałaby do tej dawnej epistemy? Powróćmy do pitagorejskiej arytmetyki i jej graficznego sympleksu. Czy nie jest on swoistym algorytmem, geometrycznym zbiorem poleceń, który można by schematycznie rozpisać na następujące etapy: „dodaj liczbę nieparzysta, zsumuj liczby nieparzyste, otrzymasz kolejne kwadraty. Lub też: dorzuć komplementarne linie, a pojawi się podobny równoległobok. Gnomon to prawo konstrukcji, reguła następstwa czy też jego zajścia” (Serres 1997, 115). Druga rzecz: obliczenia szerokości geograficznych na podstawie cienia rzucanego przez słońce podczas przesileń słonecznych i równonocy pozwoliły na powstanie tak zwanych tablic cięciw, a więc długich list stosunków między długością boków trójkątów prostokątnych a szerokością ich kątów, w czym dostrzega się początki trygonometrii. „Z jednej strony pamięć, z drugiej gnomon: maszynie odpowiada tablica, do automatycznego poznania dołącza mnemotechnika” (Serres 1997, 107).

W konsekwencji przejście od geometrycznych elementów i dokonań wplecionych w badania geograficzne, astronomiczne, zorganizowanych wokół gnomonu, do bliskiej nam geometrii euklidesowej, dokonuje się w głębi dużo donioślejszego wydarzenia w historii 
europejskiej myśli, jakim jest zwrot od racjonalności algorytmicznej do racjonalności aksjomatycznej, bazującej na dedukcji i dowodzeniu. Jak Serres próbuje zrozumieć ten zwrot? Aby odpowiedzieć na to pytanie, musielibyśmy w tym momencie wniknąć w jego szczegółowe analizy Platońskiego Menona, dowodu apagogicznego dotyczącego przekątnej w kwadracie o boku 1 i tak dalej. Możemy jednak już w tym momencie przerwać rekonstrukcję zaproponowanego przez Serres'a ujęcia genezy geometrii, ponieważ te kilka stron, które mu poświęciliśmy, w zupełności wystarczą do ukazania jego strukturalistycznej specyfiki.

Po pierwsze zatem, widać wyraźnie, jak sam przedmiot namysłu - geometria zostaje rozłożony na pewien system elementów, aspektów, relacji (podwójny geometryczny zapis, wyeliminowanie kakografii, abstrakcyjna przestrzeń umożliwiona przez gnomon itd.). Zanim postawimy pytanie o pochodzenie jakiegoś historycznego zjawiska, musimy najpierw zrozumieć je możliwie kompleksowo, w całej jego złożoności, słowem: jako pewną strukturę (w podstawowym znaczeniu tego słowa). Prowadzi to oczywiście do wniosku, że również analiza genetyczna powinna być wielowymiarowa. Starając się uchwycić narodziny geometrii w formie złożonej struktury, trzeba - niejako równolegle - zrekonstruować i wydobyć całą wiązkę procesów, transformacji, wykluczeń i inkluzji, które musiały zajść, ażeby coś takiego jak geometria mogło się ukonstytuować. To zaś implikuje kolejne cechy swoiste dla omawianego ujęcia: rekonstruowane procesy i przekształcenia należą do oddalonych od siebie i heterogenicznych porządków (nie tylko myślowych czy mentalnych, ale również społecznych, technicznych, materialnych i innych). Kontakty grecko-egipskie, dwa systemy językowe, platońska z ducha filozofia dialogu, mnemotechniczne artefakty, praca gnomonu... Rzeczywiście, myśl strukturalistyczna ma coś wspólnego z surrealistycznym gestem, wyznanie jednego z jej adeptów można uznać za credo całego ruchu:

Jak głęboko sięgam pamięcią w dzieje mojej pracy, taka w istocie była zawsze moja ambicja: doprowadzić do łączności pomiędzy tym, co według przyjętych kryteriów badania historycznego w naturalny sposób się ze sobą nie łączy. Jestem doskonale świadom tego, że niektóre skojarzenia [...] mogą się wydawać równie niezwykłe (jeśli nie równie piękne), co przypadkowe spotkanie, o którym mówił Lautréamont, „na stole prosektoryjnym maszyny do szycia i parasola” (Vidal-Naquet 2003, 14). 
Związana jest z tym, co oczywiste, specyficznie strukturalistyczna wrażliwość na wielorakie izomorfizmy, które da się wyodrębnić w analizowanym polu. Pod tym względem zaprezentowany wyżej przykład wydaje się obfitować w tego typu rozpoznania: Serres dostrzega korelację między podwójnym zapisem w geometrii a złożeniem egipskiego ideogramu z greckim alfabetem; między modelem udanej komunikacji, sokratejskim dialogiem a jednoznacznym uniwersum matematyki; między przejściem od epistemy algorytmu do epistemy dedukcji a przejściem od geometrii gnomicznej do geometrii euklidesowej... Wreszcie ostatnia uwaga: pytanie o źródła danego zjawiska nie jest tutaj pytaniem o jego przyczyny. Skupiając się na wykreślaniu kolejnych genez geometrii, Serres nie buduje jakiegoś zbioru zależności kauzalnych. Chodzi mu raczej o wyszczególnienie możliwie wielu procesów i zmian, które składaja się - także w funkcji warunkowej - na fakt historycznego zaistnienia takiej całości, jaką tworzy geometria.

Do ukazania tych ogólnych cech strukturalistyczno-historycznego mariażu w podejściu do kwestii genezy posłużył nam przykład zaczerpnięty z dzieła Michela Serres’a. I rzeczywiście, jest to przykład: z podobną formalnie próbą mamy bowiem do czynienia chociażby w eseju Jean-Pierre’a Vernanta Źródła myśli greckiej. Również prace Foucaulta dotyczące narodzin psychiatrii, kliniki czy więzienia w dużej mierze wpisują się w tę perspektywę. Jak moglibyśmy podsumować jej najważniejsze zalety, na które pośrednio wskazywaliśmy już wcześniej?

Lévi-Strauss pisał: „Wyjaśnienie naukowe nie polega na przechodzeniu od złożoności do prostoty, lecz na zastępowaniu złożoności mniej zrozumiałej przez bardziej zrozumiała” (Lévi-Strauss 2001, 329). Myśl o inspiracjach strukturalistycznych próbuje dochować wierności tej tezie. Kiedy więc, przykładowo, stawia się pytanie: jaka była geneza geometrii? jakie są źródła współczesnej praktyki karania? wyzwanie polega na tym, aby sprostać empirycznemu, logicznemu i strukturalnemu bogactwu badanego zjawiska oraz jego wyłaniania się w czasie, aby oprzeć się pokusie redukcji rzeczywistości do jednolitych elementów, które są zrozumiałe same przez się, oraz do mgliście bądź ogólnie pojętych zmian, którymi klajstruje się nawet najbardziej radykalne nieciagłości. Foucault mówi w tym kontekście o procedurze „demultiplikacji kauzalnej” (Foucault 2001, 843), o zastapieniu grubo ciosanej przyczynowości przez subtelną konstrukcję wokół badanego wydarzeniaprocesu „wielościanu inteligibilności”, którego liczba boków, a więc konkretnych praktyk, transformacji, procesów rozjaśniających to wydarzenie, jest potencjalnie nieograniczona (vide 
Serres'a proliferacja genez). Heterogeniczność porządków, jakie bierze się w takiej analizie pod uwagę, pozwala z kolei na uniknięcie traktowania historii jako zbioru równolegle ewoluujących linii rozwojowych, a taki obraz zdają się zakładać wszelkie interpretacje wyprowadzające późniejsze stany ze stanów wcześniejszych bez wykraczania poza dziedzinową sferę „tego samego”. Łącząc w genetycznych dociekaniach formy mentalne z formami społecznymi, splatając naukę z przemianami politycznymi, technicznymi lub instytucjonalnymi, Serres, Foucault bądź Vernant przełamują sztuczne podziały historycznego świata, których uzasadnienie można dziś jedynie znaleźć w subdyscyplinarnych walkach o własne poletka badawcze. Najistotniejsze jednak, że perspektywa ta sprawdziła się w konkretnych badaniach, że - jak widzieliśmy na przykładzie ujęcia przez Serres’a kwestii pochodzenia geometrii - są to oryginalne, zaskakujące, a jednocześnie świetnie ugruntowane, zarówno teoretycznie, jak i empirycznie, analizy.

Czy jednak w dzisiejszych czasach jest jeszcze dla nich miejsce? Zaryzykujmy na koniec pewną luźną analogię. Otóż w termodynamice istnieje pojęcie stanu atraktorowego, a więc stanu, który dla danego izolowanego układu jest stanem najbardziej prawdopodobnym, który go przyciaga i od którego nie oddali się on „z własnej nieprzymuszonej woli” (Prigogine, Stengers 1990, 133-134). Chodzi o stan równowagi, maksymalnej entropii, o stan bez̧ładu. Nie ulega wątpliwości, że w aktualnym układzie epistemologicznym naszej humanistycznej czy - zgodnie ze wspomnianą na wstępie hipoteza - kulturologicznej wiedzy ów stan atraktorowy, jeśli chodzi o problematykę genezy, wyznaczaja proste, przeważnie dwuczłonowe i zawieszone w teoretycznej próżni schematy kauzalne. Termodynamika wyróżnia jednak także układy dalekie od równowagi, tak zwane struktury dyssypatywne, których rozwój w czasie idzie w parze ze wzrostem uporządkowania, z procesami samoorganizacji, z malejącą miarą bezładu. Pilnie i nieustannie wypatrujemy narodzin podobnych struktur w naszym myśleniu o dynamice współczesnej i minionej rzeczywistości. 


\section{Wykaz literatury}

Arystoteles. 1006. Metafizyka, t. 1. Tłum. T. Żeleźnik. Lublin: KUL.

Braudel, Fernand. 1999. Historia i nauki spoleczne: dtugie trwanie. W: tenże, Historia i trwanie. Tłum. B. Geremek. Warszawa: Czytelnik.

Descombes, Vincent.1997. To samo i inne. Czterdzieśsi piéć lat filozofii francuskiej (1933-1978). Tłum. B. Banasiak, K. Matuszewski. Warszawa: Aletheia.

Euklides.2016. Elementy (http://www.matematycy.interklasa.pl/euklides/2/ -7.07.2016) Florczyk, Maurycy.2015. Fikcje I, II. Projekt archeologii humanistyki radykalnej. W: Foucault: źródtal ujścia, red. M. Falkowski, K. Pacewicz, C. Zgoła, Kraków-Warszawa: EperonsOstrogi.

Foucault, Michel. 2001. Dits et écrits. t. II. Paris: Gallimard.

Foucault, Michel.2000. Powrót do historii. W tenże, Filozofia-bistoria-polityka. Wybór pism. Tłum. D. Leszczyński,L. Rasiński. Warszawa-Wrocław: PWN.

Herodot.2016. Drieje. Tłum. S. Hammer (http:/ / biblioteka.kijowdski.pl/antyk $\% 20$ grecki/\%20herodot $\% 20-\% 20$ dzieje.pdf 7.07.2016)

Husserl, Edmund.1991. O pochodzeniu geometrii, Tłum. Z. Krasnodębski. W Wokót fundamentalizmu epistemologicznego, red. S. Czerniak, J. Rolewski. Warszawa: IFiS PAN.

Lévi-Strauss, Claude.1970. Myśl nieoswojona Tłum. A. Zajączkowski. Warszawa: KR.

Nagel, Ernest.1970. Struktura nauki. Tłum.zbiorowe. Warszawa: PWN.

Patras, Frédéric.2014. Géométries. W Dictionnaire d'histoire et philosophie des sciences, red. D. Lecourt. Paris: PUF.

Prigogine, Ilya, Stengers Isabelle.1990. Z chaosu ku porzadkowi. Tłum. K. Lipszyc, Warszawa: PIW.

Ritter, James.1997. Babylone - 1800. W Eléments d'histoire des sciences, red. M. Serres. Paris: Larousse.

Serres, Michel.1997. Gnomon: les débuts de la géométrie en Grèce. W Eléments d'bistoire des sciences, red. M. Serres. Paris: Larousse.

Serres, Michel.1982. Hermes. Literature, Science, Philosophy. Baltimore-London: The Johns Hopkins University Press.

Serres, Michel.10993. Les origines de la géométrie. Paris: Flammarion.

Vidal-Naquet, Pierre.2003. Crarny towca. Tłum.zbiorowe. Warszawa: PIW. 
Tomasz Falkowski - pracuje w Zakładzie Metodologii Historii i Historii Historiografii IH UAM w Poznaniu. Studiował w Toruniu (UMK), a także Poznaniu (UAM) i Paryżu (Paris I, EHESS). Główne prace: Myśl i zdarzenie, Universitas, Kraków 2013; Foucault. Historiozofia źdarzenia, WN UAM, Poznań 2014. Najważniejsze przekłady: Marc Ferro, Kino i historia, PWN, Warszawa 2011; Maurice Blanchot, Przestrzeń literacka, PWN, Warszawa 2016. Zainteresowania badawcze: historia historiografii, historia nauki, współczesna humanistyka francuska.

\section{DANE ADRESOWE:}

Instytut Historii UAM

ul. Umultowska 89d

61-614 Poznań

EMAIL: tmfalko@amu.edu.pl

CYTOWANIE: Falkowski, Tomasz. 2016. Pochwała donkiszoterii, czyli o tym, co strukturalizm wniósł i wciąż może wnieść do historii. Praktyka Teoretycżna 4 (22): 88-104.

DOI: $10.14746 /$ prt.2016.4.5

AUTHOR: Tomasz Falkowski

TITLE: An apology for quixotism, or how history has been influenced by structuralist and post-structuralist thinking

ABSTRACT: The paper discusses various possibilities of using structuralism in the current historical research. It seems, e.g., that this methodology or mode of reasoning could still be helpful to understand the origins of some historic phenomena. Despite the widely-held belief, the most important thinkers associated with structuralism, such as Jean-Pierre Vernant, Roland Barthes, or Pierre Vidal-Naquet, did not reduce their interests to the study of synchronic relations, but - as Foucault put it - attempted to fashion the instrument for a precise historical analysis. It was also a case of Michel Serres' reflection on the origins of geometry. This example is closely examined in the paper to indicate some differences between both traditional and structuralist approaches to that question.

KEYWORDS: structuralism and history, validity of structuralism, origins of geometry, Michel Serres 